\title{
Education and Training in Forensic Intelligence : A New Challenge
}

Frank Crispino, Quentin Rossy, Olivier Ribaux, Claude Roux

\begin{abstract}
From recent calls for positioning forensic scientists within the criminal justice system, but also policing and intelligence missions, this paper emphasizes the need for the development of educational and training programs in the area of forensic intelligence, It is argued that an imbalance exists between perceived and actual understanding of forensic intelligence by police and forensic science managers, and that this imbalance can only be overcome through education. The challenge for forensic intelligence education and training is therefore to devise programs that increase forensic intelligence awareness, firstly for managers to help prevent poor decisions on how to develop information processing. Two recent European courses are presented as examples of education offerings, along with lessons learned and suggested paths forward. It is concluded that the new focus on forensic intelligence could restore a pro-active approach to forensic science, better quantify its efficiency and let it get more involved in investigative and managerial decisions. A new educational challenge is opened to forensic science university programs around the world: to refocus criminal trace analysis on a more holistic security problem solving approach.
\end{abstract}

\section{Introduction.}

At a first glance, forensic intelligence may simply appear as a new function of forensic science facilitated through expanding capabilities in information technologies (computers, databases, dataflow management softwares). However, more in-depth considerations show that forensic intelligence actually embodies a real and new willingness of forensic practitioners to be involved in investigative and policing strategies. By doing so, it also makes existing practices in the scientific literature more explicit and more visible. A more complete adoption of forensic intelligence requires moving away from the dominant conception of a patchwork of disciplines only assisting the criminal justice system towards the view of a science that studies the informative potential of traces, remnants of a criminal activity (Margot, 2011a). Enabling this change may be a major challenge for education in order to open the learners' mind to accept concepts and methods in forensic intelligence.

This goal can be approached by a return to the historical roots of forensic science. It consists in remembering that, in 1909, Reiss developed an integrated forensic science academic program in Switzerland, and that Vollmer saw the policeman as 'Scientific' in the broad sense, and articulated his course around fundamental sciences, criminology, and law (Vollmer, 1930). This conception 
continued to crystallise through the foundation of the School of Criminology at the University of California, Berkeley, with Paul Leland Kirk, the founder of Criminalistics (Regional History Office, 1972, 1983). Through these programs it is easier to realise how, since this early period, the integrated conception of forensic science has been diluted by specialisation, focus on technologies, and normative procedures. As a result, forensic science is at risk of being engaged in inceptive and silo-compartmentalized technicalities and imprisoned by batteries of standards (Roux et al., 2012). Finally, it can be assumed that this mechanism has also largely hampered articulating forensic science with intelligence, which has itself evolved as a subject that is difficult to study and comprehend by outsiders to the intelligence community (Brodeur, 2007).

Positioning forensic science as a holistic discipline with strong links to intelligence facilitates the development of educational and training programs in the area of forensic intelligence. These programs can also capitalise upon the significant theoretical material already available. However, such a vast working field requires further academic coordination. Education should be intensively and continuously fed by research (Ribaux et al. 2010a). Further, such development cannot occur in a vacuum, without considering the many practitioners in the system that are directly concerned with forensic intelligence. Who should be the beneficiaries of such training? Forensic scientists including crime scene examiners (CSEs), police managers or investigators, magistrates and crime intelligence personnel. Such questions underline the need for specific education across various and different communities supposed to share common and ultimate goals of crime solving and crime prevention. We argue in this paper that the first communities to target are police and forensic science managers, because they are key personnel with decision making power who may decide to challenge the specialist approach. We assume this key group suffers from the common confusions around the term 'forensic intelligence', especially as they generally do not distinguish between general computeraided criminal data-flow management and forensic intelligence. Indeed, the education of forensic intelligence practitioners is underpinned by the establishment of intelligence-led decision-making processes and structures that are the responsibilities of managers. Integrating information technologies and training personal cannot be considered as sufficient measures. For this reason, seminars to better assess forensic intelligence capabilities can be delivered as part of these initiatives.

Indeed, two new complementary and exploratory training initiatives recently occurred in Europe, trying to fill the gap between the different communities involved in the generation and use of forensic intelligence. The first was a one week course supported by a grant from the Collège européen de police - European College of Police (CEPOL) for a week in Paris in June 2012. The course was organized by the Central criminal agency of the French gendarmerie (Pôle judiciaire de la gendarmerie nationale) and dedicated to senior police managers and investigators. The second 
course occurred in September 2012 at the Ecole des sciences criminelles in Lausanne, Switzerland, and jointly targeted CSEs, crime analysts and forensic scientists. Both courses received positive feedback from participants. Such courses ultimately proposed strategic directions on how to enhance forensic intelligence within the broader education framework of forensic science.

\section{I - Educating Managers and Practitioners to Address Critical Imbalance ?}

Police personnel have produced law enforcement intelligence for about 30 years through computing and crime analysis capabilities. Therefore, it is not surprising that both police operational managers and decision-makers at political levels feel they havea good understanding of forensic intelligence. However, this is a fallacy, because the managerial conception is shaped by the view of forensic science as entirely dedicated to the Court and technologically based, significantly diminishing the informational potential of traces in intelligence and investigation. This view, largely fed by the attitude of the forensic science community itself, favours solutions that are easier to accept in a media-shaped concept of the discipline. This is a fertile territory for practitioners who, by their own interests or overconfidence in the value of their methods and technologies, tend to impose their solutions. The challenge for forensic intelligence education and training is to devise programs that increase forensic intelligence awareness for managers and help prevent poor decisions on how to develop information processing in policing.

A salient illustration of this mechanism is the belief that behavioural profiling is the most relevant means to distinguish patterns and series in crime data. This appears to justify significant investment in the development and running of databases. The first widespread law enforcement (LE) intelligence systems appeared in the USA in the mid-80's with the Violent Crime Analysis Programme (ViCAP). This was complemented by the Automated Modus Operandi System (AMOS) in the early 90's, and followed by similar programmes in Canada (ViCLAS for Violent Crime Linkage Analysis System) (Collins et al.1998) superseding the Major Crime File (MCF), the UK (HOLMES I and II for Home Office Large Major Enquiry System) (Walsh, 2009). Some countries (for instance, Australia, Austria, Belgium, England, Germany, the Netherlands, New Zealand and Switzerland) followed this criminal IT strategy with little if any real critical conceptualisation. For example, France adopted the Canadian tool as such in 2003 and activated it in 2006 for homicides, rapes, and missing persons. The managerial integration of these tools was typical. A database was supposed to implement a cutting-edge methodology for the analysis of serial crimes. No serious questions were raised about their implicit fundamental theoretical underpinnings or their efficiency (Bennell et al., 2012). The technology was there, as a proof of the value of the approach. Vocal profilers, victims associations and scholars promoted this approach. The focus on the psychology of the criminal was rather welcome in a police force which is daily confronting human beings. These parameters and the fact that it was the sole system available 
were sufficient for managers to decide its wide-spread adoption: presented as an innovative technology. Not being part of these 'progresses' would be seen as poor management (Dupont 2001).

More than 30 years later, it became clear that these initiatives neither addressed the organizational deficiencies of police information systems synthesised by Sheptycki (2004) in a tangible manner, nor took into account expressed rational criticism about the real efficiency of such tools. These solutions are often described as "black holes" containing less than $10 \%$ of reported homicides, which were their primary, if not exclusive focus (Witzig, 2003). Further, the reliability and accuracy of their data is still to be demonstrated (Harman, 1997 ; Davey, 2001; Ratcliffe, 2008 ; Snook et al., 2012).

As both a serious crime unit manager and a forensic scientist, one of the authors was tasked by a central coordination unit to complete up to 163 questions over 39 pages with sparse requests on forensic exhibits and only on those with high discriminatory power (DNA, fingermarks, ballistics). This was obviously for identification purposes, rather than with the idea of linking crimes. It even appears that police database systems did not foresee the potential of forensic traces to elaborate crime intelligence on volume crimes (Impini, 2006 ; Crispino, 2006; Rossy et al., 2013). Unfortunately, their effectiveness to solve serious crime cases is still being questioned (Strom et Hickman, 2010).

Indeed, a thorough analysis of some of the references provided in this article could even raise, if not support, the hypothesis that the few published behavioural linking successes could have been more efficiently, if not more quickly solved through a better coordination of existing information, and a better integration of forensic case data (Ribaux et Margot, 2003 ; Ribaux et al., 2006).

Despite the arguments presented above, we do not claim that behavioural profiling database systems have no consistency, nor that behavioural science is unreliable as far as it is rationally founded on physical traces with a strong empirical basis (Turvey, 1999 ; Turvey et McGrath, 2006). It just means that they were originally designed to assist analysts to work more efficiently (Grubin et al., 2001), and to reduce linkage blindness (Egger, 1984 ; Kean et Hamilton, 2004). This objective seemed to have been in a sense better achieved by the positive side-effect of promoting cross comparisons of cases by implementing an exchange platform, rather than by the use of the specific poorly conceived computerised databases. Montague's claim confirms this view: "the most significant value of ViCLAS... (is) that [it] generated linkages [that] put investigators across the country [in touch] with each other to share case information and develop working relationships that could have payoffs in future cases" (Montague, 2002). From a forensic intelligence viewpoint, the problem resides not in the principle of improving systemic comparisons 
of crimes data, but rather in the imbalance of the global architecture of such systems that fail to situate forensic case data at a place that properly exploits its informational potential.

For the forensic science community, it also means that police managers and leaders, in the criminal intelligence or investigative services are only loosely aware of forensic science, in general, and of the various tests that could be requested, in particular. Financial constraints and legislative compliance primarily considering crime on a case-by-case basis (Crispino, 2009), and a wide discretion of decision-makers to explain their forensic resource allocations could potentially inhibit the optimal usage of forensic science for global security purposes (Tilley et Ford, 1996). This is especially so today as forensic scientists are being increasingly disconnected from law enforcement agencies following a number of trends prompted by the NAS report (NAS, 2009), if not promoted by scholars (e.g. Cole, 2013), amongst other things.

The critical question becomes how can we explain to decision-makers that forensic case data are available at some location - generally a state police laboratory - not only to support or exclude a common source hypothesis, but also to identify crime series and to provide intelligence at tactical, operative, strategic and, ideally, political levels.(Ribaux et Margot, 2007).

If increasing managers' awareness is a precondition for providing a favourable framework for the development of forensic intelligence, education and training can also target all the other communities concerned with the generation and use of intelligence. This will allow complementing the managerial top-down development of forensic intelligence by a 'bottom-up' practical approach. The critical questions therefore becomes: How can we teach crime scene examiners and practitioners of other forensic science disciplines that their work in the field not only encompasses resolution of the case in hand, but is also an integral part of the threat assessment within their jurisdictions? What kind of pragmatic models should we develop for forensic intelligence so it becomes acceptable to the various communities involved (LE, forensic science, intelligence, IT, and managerial)?

\section{II - Recent European initiatives in forensic intelligence education.}

Entitled 'Forensic science and policing: Forensic interpretation and intelligence' the first international European seminar on forensic intelligence granted by the European College of Police (CEPOL) took place for a week in June 2012 This course welcomed 25 police managers and forensic practitioners from around Europe at the General Directorate of the French Gendarmerie . It did not limit itself to present forensic applications for police intelligence assessment at operative and strategic levels (e.g. chemical profiling of accelerants - France (Haraczaj et al., submitted, 
under peer-review $^{1}$ )-, drugs - Switzerland (Ioset et al., 2005 ; Ratle et al., 2007) -, physical profiling of shoemarks - the UK (Rix, 2004 ; Girod et al., 2008)-, or the European initiatives to ease forensic data-flow between its member states (intervention of Europol -), but also addressed the very notion of trace valuation into proof through semiotics, logics (Peirce, 1898 ; Eco, 1988 ; Inman et Rudin, 2002 ; Dulong, 2004 ; Pottier et Planchon, 2011), and Bayesian tools (Aitken et Taroni, 2004 ; Champod et Vuille, 2011).

Presented with results of DNA statistical surveys (Briody et Prenzler, 2005) or with some mythical views that forensic science solves serious cases on its own (Mucchielli, 2006) or contributes to volume crime reduction (Bradbury et Feist, 2005), attendants started to question the efficiency of forensic assets for policing. In line with Barclay (2009), they finally called for a better coordination between police needs and forensic skills, with a more holistic integration of information conveyed by traces and behavioural analysis into the intelligence process beginning with the management of crimes scenes. A final workshop enabled investigators and forensic personnel to mix and identify the role of an investigative forensic coordinator (Crispino et al., 2009 ; Schuliar, 2009), for which French, British, German and Belgian models had been presented.

In September 2012, the first session of a new training course entitled "Forensic and Crime Intelligence" ("Renseignement forensique et criminel" in French) took place at the University of Lausanne, Switzerland ${ }^{2}$. The training course at the University of Lausanne, Switzerland, brought together fifteen CSEs, forensic scientists and crime analysts from Switzerland and France and questioned the relations between forensic science and crime intelligence. This continuous training program dedicated to practitioners was built upon three academic courses covering "forensic intelligence", "crime analysis" and "criminal intelligence analysis" provided over the last fifteen years at the ESC. Forensic science graduates from this institution are already aware of these models when they start their professional activities, facilitating an interest for such training amongst work colleagues and managers ${ }^{3}$.

Starting with a critical discussion on forensic science efficiency (e.g. in regards to traces leading to Court decisions), the use of forensic case data for crime linkage analysis (Ribaux \& Margot,

\footnotetext{
Interestingly, the strategy of analysis of (at that time) unburnt gasoline developed at the Gendarmerie laboratory for quick and cheap intelligence purposes - for example, to be applied during riots, or series of arson -, based on GCFid coupled with a quality-control software used for years by an independent French organism to check the quality of gasoline from various oil-companies through the collection and integration of mass and volume-ratios of different compounds, was originally rejected by a top-ranked forensic science peer-reviewed journal in June 2012 . It did not point methodological or scientific inconsistencies, but a technology which was superseded in sensitivity by GC-MS ; hence, of little interest for the forensic community! This strategy is commonly used in the French gendarmerie laboratory, and integrated in its Quality management manual, speeding investigations and optimizing ressources allocation, that are at the core of forensic intelligence...

http://www.formation-continue-unil-epfl.ch/renseignement-forensique (last access : 4th october 2012)

In the context of prompting a cultural change that is supported by the senior management, it is also interesting to note that forensic science graduates from ESC currently occupy managerial positions in a number of police forces in Switzerland, including three of them at the level of State Chief Police Commissioner.
} 
2003; Ribaux et al., 2006) and for investigative purposes (Kind, 1987) the course broadened the scope of forensic science beyond its role as court evidence and defined the framework for the week. In addition to considering the impact of forensic case data on crime linkage analysis (Rossy et al., 2013), intelligence-led strategies applied to crime scene investigation were also discussed and exemplified through a case study exercise (Ribaux et al., 2010b).

Subsequently, the second aim of the training was to provide methodological clues to enable participants to initiate or consolidate their own intelligence-oriented strategies. Indeed, it is assumed that behind the technical specialities of each stakeholder (e.g., CSEs, forensic scientists, investigators, crime analysts or criminal intelligence analysts), there is a shared problem of data handling (mainly due to the complexity or quantity of collected information). The course providers argue that this issue may be addressed through a common methodology (e.g. the intelligence process) and shared techniques. However crime investigation and more particularly forensic science tends to suffer from an over specialisation (Roux et al., 2012); how can a new layer of techniques be introduced to provide forensic science efficiency? Although this assumption is not yet formally evaluated, the proposed approach favours the selection of promising information visualisation techniques. The use of these techniques was addressed through main dimensions to investigate crime problems: link analysis, temporal analysis and spatial analysis. Indeed, each of these general perspectives allows the selection of the most appropriate and effective visual form. Tutorials were based on best practices formalized as patterns describing particular solutions to recurring analysis questions, such as the use of maps and event charts to support the detection and follow up of serial crimes or the conception of link charts to keep a global view on complex cases and to ease the selection of specimens to submit to laboratories (Rossy, 2011; Rossy \& Ribaux, 2014).

The course ended with break-out sessions. Participants were asked to elaborate intelligence products in regards to a particular context they had chosen (i.e. to communicate with investigators or magistrates on a complex case or to produce a weekly bulletin for CSEs, etc.). Interestingly, five groups produced five completely distinct products that led to a final and global discussion on the roles of intelligence-led strategies. In particular this discussion attempted to clarify the apparent contrast between crime analyst and forensic scientist perspectives.

\section{III - Lessons Learned and Suggested Paths to Move Forward}

Conceived separately for different populations relevant to criminal investigation and policing, these two training programs reached a similar conclusion: there is a strong need for a better integration of forensic science in intelligence-led policing (Ratcliffe 2008; Ribaux 2010). This is 
not only the investigation process (tactical analysis), but also for pattern recognition of repetitive crimes (operative analysis), that could help optimise policing resources (strategic and political analysis).

As a basic illustration, an in-field triage function (i.e. how to optimise specimen collection at crime scenes to ensure value that accounts for policing needs was rapidly identified as missing in both seminars. This triage function is one of the gaps identified between intelligence, investigative and forensic functions. Participants were in agreement and admitted that forensic scientists focus on physical aspects of the trace (e.g. nature, substrate, preservation, techniques for analysis) and are rarely concerned with modus operandi, the immediate physical and social environment in which the trace has been left, and the crime problems it is related to. Investigators cannot reasonably assume the triage responsibility. They generally have interpreted carefully the immediate environment surrounding the crime, but they do not accurately use it to make submission decisions because they see the contribution of forensic science through well-known outcomes that are formalized by routine analysis products, regardless of the broader context of the case.

Reality expressed by forensic scientists participating in the seminars is that they rarely know the follow-up of their work in investigation and they are sometimes frustrated to respond to specific requests without considering the overall contribution they may give to the case or crime problems. This is only one example of a more global lack of integration between forensic science, investigation and intelligence. Indeed, the submission of specimens may also be guided by their potential to detect series and in return, knowledge about the crime environment surrounding the case may give helpful clues. Such articulations through three strata (physical, situational and intelligence) may benefit the process of forensic investigation of crime from collection of traces to dissemination of forensic outcomes for intelligence, investigative, or court concerns. This interconnection is required as it is otherwise difficult for forensic scientists to grasp policing and justice constraints and difficult for police stakeholders to apprehend the full contribution forensic science may achieve.

\section{The use of knowledge already expressed in education programs.}

In order to achieve this integration, from a methodological point of view, the aim of education and training in this field is to provide modern forensic and police personnel with the skills to manage methods that facilitate the treatment of complex forensic trace data (by their diversity, split and quantity) for intelligence and/or investigative purposes. Until now, a lot of energy has been dedicated to carefully express what distinguish investigators, crime analysts, and forensic scientists. However, the integration of forensic science with intelligence-led policing requires a rethink. That is what do they share? What methodology can emerge from this review? Indeed, 
forensic intelligence has already given an indication of a substantial part of this knowledge. For instance, criminal intelligence analysts support investigation by processing crime data in a structured way. Their methods can be used to integrate information conveyed by traces in appropriate models and data structures, guide their treatment through the steps of intelligence processes, as well as facilitate their interpretation by using various visualization methods and tools (Rossy, 2011; Gwinn et al, eds, 2008; Milne, 2012). The key aspects for implementing such methodology is that analysts of forensic case data should possess a strong forensic culture, or be paired with a forensic scientist, as opposed to scientists reporting " "in vacuum” without any regard to the context of the event that produced the evidence in the first place" (Quarino et Brettell, 2009). Theoretical material, operational applications and education in forensic intelligence are increasingly available. However, what is still lacking is a clear view of who must do the job, and how it has to be organised.

Bringing together participants in our seminars with different backgrounds and functions was highly informative from this perspective. Whatever our preference and the chosen model, forensic education and training should account for these perspectives.

\section{Collaborative work or generalist's functions.}

The choice as to who does the job and how it is organized is obviously a managerial decision. Any solution strongly relies on political, security and education considerations that are variable across different jurisdictions and that may be influenced by the public or private status of the provider(s). However, it is possible to broadly distinguish two prevailing views:

1. a multidisciplinary approach consisting of increasing synergies between 'specialists' (mainly investigators, forensic scientists and crime intelligence analysts). This integration may be implemented through investigative teams bringing together psychologists, forensic scientists, crime intelligence analysts and investigators (Barclay, 2009). This is even applicable at the level of an elementary jurisdiction: "as smaller services can achieve best results due to their working environment of sharing information between colleagues working on different branches of crime analysis, intelligence sources and forensics" (Milne, 2012, p. xix);

2. a generalist's perspective that focuses on criminal trace analysis in the holistic context of security problem solving. This view follows the Lausanne's academic model that finds its root with Reiss in 1909 (Margot 2011). Beyond the fact that many practitioners have followed this educational path, this solution seems to emerge pragmatically for instance through a middleman to join the dots between the police and the laboratory worlds or the development of functions such as forensic intelligence analysts. 
Both views require education and training to focuses on how to stimulate and implement collaborative frameworks for problem solving. However, if the first approach is chosen as a preliminary step forward, education and training will primarily focus on awareness efforts addressed to the specialist communities rather than on integrating each others' knowledge in a holistic manner. Conversely, if the second approach prevails, integrated academic programs in forensic science will result. They will avoid focusing on specific technologies and propose a more holistic perspective on crime traces; in particular on how to collect traces and take advantage of the information they convey in crime problem solving. This can be done through considering forensic intelligence as a sub-discipline of forensic science, which considers the existing body of knowledge to be developed through dedicated research. However, for the sake of its own internal coherence, should forensic science continue to spell out the distinctions between forensic intelligence, investigation and evaluation? The diversification of roles compounded by the development of forensic intelligence, may unwillingly create separate communities. In order to keep forensic science as a whole, models and methods used to interpret the possible significance traces can have in regards to their context of use (i.e. prevention, case linking and solving, criminal structures assessment, resources allocation, etc.) should be carefully related to each other in education programs and research. For instance, presenting evidence in court ('forensic evaluator') may benefit from such integration, since it is traditionally addressed through the Bayesian evaluative model and also increasingly through visual forms such as link charts used by criminal intelligence analysts ('forensic investigator and analyst').

In summary, if we clearly mark our preference for a generalist perspective, opportunities and challenges pertaining to the two positions described above will continue to generate further hot debates that are beyond the scope of this paper (Laurin, 2013; Cole, 2013). In any case, the importance of elaborating a coherent strategy that has the potential to overcome silos caused by specialisms is another strong argument for police and intelligence managers to attend forensic symposia and conferences dealing with collection and scientific interpretation of evidence and participate in forensic research endeavors.

\section{Pedagogical issues.}

This kind of scientific education should be oriented towards problem solving. Skills in forensic intelligence should not only rests on a clinical approach, but also contribute to the development and evaluation of hypotheses leading to decisions involving forensic analysis (De Forest, 1999). Such methodological shifts raised new challenges. Traditionally, forensic education is based on simulated case discussion. However such pseudo in situ scenarios can neither adequately address the topic of intelligence-led crime scene examination, nor the exploitation of forensic case data for linkage analysis. Designing education and trainings for forensic intelligence analysts or a team 
capable of handling such questions raises its own challenges. The first difficulty is the availability of data. It is almost impossible to create simulated police databases. Data should be obtained from police LIMS systems to create appropriate exercises, which may be difficult in some jurisdictions because of privacy, security and confidentiality considerations. Secondly, as forensic intelligence analysts require information processing skills, a new layer of technical competencies should be included in training programs.

Without such background, forensic intelligence may tend to focus more on mastering tools than on problem solving. Furthermore, technological choices are critical since they may not be available in police organizations. Forensic intelligence education implies a strong relationship between the academic, forensic scientist and police worlds.

\section{The forensic science community to take the initiative.}

From this background, and as illustrated by the two examples of training initiatives presented above, there is some consensus that it is up to the forensic community to stimulate the development of forensic intelligence by providing such seminars and explain its role and services and adapt to the various stakeholders. This is further corroborated by the recent European Academy of Forensic Science conference hosted in the Netherlands late August 2012, which offered a theme dealing with education, training and assessment of professionals in the criminal justice system. It could follow from this preliminary assessment that such a forensic educative framework able to carry out this kind of gap-bridging program should emerge from the forensic community itself.

\section{Conclusion.}

While the NAS report initiated a strong call for a research culture within the forensic community to tackle its deficiencies (Mnookin et al., 2011), few authors identified the lack of forensic science culture and dared to call for a change of paradigm in forensic science, in general, and in forensic science education in particular (Margot, 2011b; Roux et al. 2012). Such a change would position forensic scientists at their most logical place (De Forrest, 1999) within not only the criminal justice system, but also the policing and intelligence missions.

The new focus on forensic intelligence could restore pro-activity to forensic science, better quantify its efficiency and enable it to be more involved in investigative decisions. A new educational challenge is open to forensic science university programs around the world: to refocus criminal trace analysis on more holistic security problem solving. This also implies (re)establishing aspects of policing, crime investigation, criminology and decision-making in core forensic science curricula. 


\section{$\underline{\text { References }}$}

Aiken C, Taroni F (2004) 'Statistics and the Evaluation of Evidence for Forensic Scientists, Second Edition', Wiley \& Sons Ltd, Chichester UK.

Association of Forensic Science Proviers (2009) 'Standards for the formulation of evaluative forensic science expert opinion', Science and Justice 49, 161-164.

Bell C (2006) 'Concepts and possibilities in forensic intelligence', Forensic Science International $162,38-43$.

Barclay, D., 2009. Using forensic science in major crime inquiries. In Handbook of forensic science, J. Fraser \& R. Williams, eds. pp. 337-358.

Bennell C, Snook B, Macdonald S, House JC, Taylor PJ (2012) 'Computerized Crime Linkage Systems. A Critical Review and Research Agenda', Criminal Justice and Behavior 39(5), 620-634.

Bradbury SA, Feist A (2005) 'The use of forensc science in volume crime investigations: a review of the research litterature', Home Office Online Report 43/05.

Briody M, Prenzler T (2005) 'DNA databases and property crimes: a false promise ?', Australian Journal of Forensic Sciences 37, 1408-1415.

Brodeur J-P (2007) 'Le renseignement II: L'analyse en pratique. Deux illustrations', in Maurice Cusson, Benoit Dupont, Frédéric Lemieux, eds, Traité de sécurité intérieure, Presses polytechniques universitaires romandes, Lausanne, Switzerland, 278-289.

Champod C, Vuille J (2011), 'Scientific Evidence in Europe - Admissibility, Evaluation and Equality of Arms, International Commentary on Evidence 9(1).

Cole S (2013) 'Forensic Science Reform: Out of the Laboratory and into the Crime Scene' Texas Law Review 91, 123-136.

Collins PI, Johnson GF, Choy A, Davidson KT, Mackay RE (1998) 'Advances in violent crime analysis and law enforcement: the Canadian Violent Crime Linkage Analysis System', Journal of Government Information 25, 277-284.

Crispino F (2006) 'La trace matérielle: Un catalyseur d'exploitation de l'information judiciaire', Revue de la gendarmerie nationale 221, 5-15.

Crispino F (2007) 'Nature and place of crime scene management within forensic sciences', Science and Justice 48, 24-28.

Crispino F, Brault J, Burgueyre P (2009) 'Le coordinateur en criminalistique. Un nouvel acteur du renseignement criminel', Revue de la gendarmerie 233, 6-15.

Davey C (2001) 'Throwing away the key on a serial sex offender', Australian Police Journal 55, 220-225. 
De Forest PR (1999) 'Recapturing the essence of criminalistics', Science and Justice, 39 (3), 196208.

Dulong R (2004) 'La rationalité de la police technique', Revue Internationale de Criminologie et de Police Technique et scientifique 57(3)/04, 259-278.

Dupont, B. (2001) 'Policing in the Information Age: Technological Errors of The Past in Perspective' in M. Enders et B. Dupont (eds), Policing the Lucky Country, Hawkins Press, Leichhardt, 31-52

Eco U (1988) 'Horns, Hooves, Insteps. Some Hypotheses on Three Types of Abduction', in: Eco U, Sebeok TA, Eds, Dupin, Holmes, Peirce. The Sign of Three. First Midland Book Edition, Indiana University Press, USA.

Eco U (1992) 'Le signe', Le livre de poche, Paris, France.

Egger SA (1984) 'A working definition of serial murder and the reduction of linkage blindness', Journal of Police Science and Administration 12, 348-355.

Girod A, Champod C, Ribaux O (2008) 'Les traces de souliers', in: Série Criminalistique, Presses Polytechniques Universitaires Romandes, Lausanne.

Grubin D, Kelly P, Brunsdon C (2001) 'Linking Serial Sexual Assaults Through Behaviour”, Home Office Research Study No. 215, Report of the Research, Development and Statistics Directorate, Home Office, London, UK.

Gwinn SL, Bruce C, Cooper JP, Hick S (2008) 'Exploring Crime Analysis. Readings on Essential Skills. $2^{\text {nd }}$ edition', International Association of Crime Analysts, Overland Park, KS, USA.

Haraczaj N, Remillon C, Ducrozet A, Sauleau C, Crispino F, Frere B, Cognon G, Hoffman A (not published) 'Forensic application of a quality control software on gasoline petroleum fractions : an intelligence approach', submitted for publication in Forensic Science International in March 2012, rejected in June 2012.

Harman A (1997) 'Inter-jurisdictional cooperation in Ontario', Law and Order 45, 106-108. Hazard D, Margot P, Ribaux O (2011) 'Pertinence de la trace : Etude théorique et perspectives expérimentales', Revue internationale de criminologie et de police technique et scientifique, RICPTS 3(11), 341-374.

Impini J-F (2006) 'Vers un service d'information judiciaire haute résolution', Revue de la gendarmerie nationale 220, 5-12.

Inman K, Rudin N (2002) 'The origin of evidence', Forensic Science International 126, 11-16. Ioset S, Esseiva P, Ribaux O, Weyermann C, Anglada F, Lociciro S, Hayoz P, Baer I, Gasté L, Terrettaz-Zufferey A-L, Delaporte C, Margot P (2005) Establishment of an operational system for 
drug profiling: a Swiss experience, Bulletin of Narcotics 57 (1-2), 121-146.

Jackson G, Champod C, Evett IW, McCrossanS (2006) 'Investigator/evaluator-a possible framework to guide thinking and practice for forensic scientist', Science and Justice 46(1), 33-45. Kean TH, Hamilton LH (2004) 'The 9/11 Report', The National Commision on Terrorist Attacks Upon the United States, St Martin's Press, New York: 593.

Kind, SS (1987) 'The scientific investigation of crime'. Harrogate: Forensic Science Services Ltd. Margot P (2011a) 'Forensic Science on Trial - What Is the Law of the Land?', Australian Journal of Forensic Science 43(2), 89-103.

Laurin JE (2013) 'Remapping the Path Forward: Toward a Systemic View of Forensic Science Reform and Oversight', Texas Law Review 91, 1051-1118.

Margot P (2011b) 'Commentary on the Need for a Research Culture in the Forensic Sciences', UCLA Law Review 58, 795-801.

Milne R (2012) 'Forensic Intelligence', CRC Press, Boca Raton, FL, USA.

Mnookin JL, Cole SA, Dror IE, Fisher BA, Houck MM, Inman K, Kaye DH, Koehler JJ, Langenburg G, Risinger DM, Rudin N, Siegel J, Stoney DA, 'The Need for a Research Culture in the Forensic Sciences', UCLA Law Review 58, 725-779.

Montague A (2002) 'RCMP's forensic support', Law \& Order 50, 50-57.

National Academy of Sciences (NAS) (2009) Strengthening Forensic Science in the United States: A Path Forward, National Academies Press, Washington, DC.

Peirce CS (1979) ‘1931-1935 Collected Papers’, Cambridge, Harvard University Press. Traduction française partielle : Ecrits sur le signe, ed. G. Deledalle, Paris, Le Seuil.

Pottier P, Planchon B (2011) 'Les activités mentales au cours du raisonnement médical diagnostique', La Revue de médecine interne 32, 383:390.

Quarino L, Brettell T (2009) 'Current issues in forensic science higher education', Analytical and Bioanalytical Chemistry 394 (8), 1987-1993.

Ratcliffe JH (2008) 'Intelligence-led Policing', Willan Publishing, Cullompton, UK.

Ratle F, Gagnè C, Terrettaz-Zufferey A-L, Khanevski M, Esseiva P, Ribaux O (2007) 'Advanced clustering methods for mining chemical databases in forensic science', Chemometrics and Intelligent Laboratory Systems 90, 122-131.

Regional Oral History Office (1972) August Vollmer: Pioneer in Police Professionalism : Oral History Transcript / and Related Material, University of California, Bancroft Library, Berkeley Regional Oral History Office (1983) August Vollmer: Pioneer in Police Professionalism. An Oral 
History conducted in 1972 The Bancroft Library, University of California, Berkeley

Ribaux O, Margot P (2003) 'Case based reasoning in criminal intelligence using forensic case data', Science and Justice 43(3), 135-143.

Ribaux O, Walsh S, Margot P (2006) 'The contribution of forensic science to crime analysis and investigation: Forensic intelligence', Forensic Science International 156, 171-181.

Ribaux O, Margot P (2007) 'La trace matérielle, vecteur d'information au service du renseignement criminel et de la résolution de problèmes', in : M. Cusson, B. Dupont, F. Lemieux, Traité de sécurité intérieure, chapter 21, 300-321.

Ribaux O, Baylon A, Lock E, Delémont O, Roux C, Zingg C, Margot P (2010a) 'Intelligence-led crime scene processing. Part I: Forensic intelligence', Forensic Science International 195, 10-16.

Ribaux O, Baylon A, Lock E, Delémont O, Roux C, Zingg C, Margot P (2010b) 'Intelligence-led crime scene processing. Part II: Intelligence and crime scene examination', Forensic Science International 199, 63-71.

Rix B (2004) 'The Contribution of Shoemark Data to Police Intelligence, Crime Detection and Prosecution', Home Office, Research, Development and Statistics Directorate, Findings London. Rossy Q (2011) 'Méthodes de visualisation en analyse criminelle: approche générale de conception des schémas relationnels et développement d'un catalogue de patterns', $\mathrm{PhD}$ Thesis, Université de Lausanne, Institut de Police Scientifique, Lausanne.

Rossy Q, Ioset S, Dessimoz D, Ribaux O (2013) Integrating forensic information in a crime intelligence database. Forensic Science International 230(1) 137-146.

Roux C, Crispino F, Ribaux O (2012) 'From Forensics to Forensic Science', Current Issues in Criminal Justice 24(1), 7-24.

Rossy Q, Ribaux O (2014) A collaborative approach for incorporating forensic case data into crime investigation using criminal intelligence analysis and visualisation. Science and Justice, in press.

Schuliar Y (2009) 'La coordination scientifique dans les investigations criminelles. Proposition d'organisation, aspects éthiques ou de la nécessité d'un nouveau métier', Université Paris Descartes, Ecole Doctorale de Paris Descartes : Droit, Gestion, Relations internationales ; Ethique médicale et et biologique. Thèse en cotutelle avec l'Université de Lausanne, Faculté de Droit et des Sciences Criminelles de l'Université de Lausanne, Ecole des Sciences Criminelles. Schuliar Y, Crispino F (in press) 'Semiotics, Heuristics and Inferences Used by Forensic Scientists', in Encyclopedia of Forensic Sciences, Academic Press, Oxford, UK.

Sheptycki J (2004) 'Organizational Pathologies in Police Intelligence Systems. Some 
Contributions to the Lexicon of Intelligence-led Policing', European Journal of Criminology 1(3), 307-332.

Snook B, Luther K, House JC, Bennell C, Taylor PJ (2012) 'The Violent Crime Linkage Analysis System. A Test of Interrater Reliability', Criminal Justice and Behavior 39, 607-619.

Strom KJ, Hickman MJ (2010) 'Unanalyzed evidence in law enforcement agencies. A national examination of forensic processing in police departments', Criminology \& Public Policy 9(2), 381404.

Tilley N, Ford A (1996) 'Forensic Science and Crime Investigation', Report of the Home Office, Police Research Group, London.

Turvey B (1999) 'Criminal Profiling. An Introduction to Behavioral Evidence Analysis', Academic Press, San Diego, California, USA.

Turvey B, McGRATH M (2006). 'Criminal profilers and the media: Profiling the Beltway Snipers', In: Petherick, W. (Ed). Serial Crime: Theoretical and Practical Issues in Behavioural Profiling, Elsevier/Academic Press: Burlington, Ma, 113-129.'

Vollmer A (1930) 'The Scientific Policeman', The American Journal of Police Science 1(1), 812.

Walsh SJ (2009) 'Evaluating the Role and Impact of Forensic DNA Profiling on Key Areas of the Criminal Justice System', Ph.D Thesis, University of technology of Sydney (UTS), NSW, Australia.

Witzig EW (2003) 'The new VICAP', FBI Law Enforcement Bulletin, June, 1-7. 